\title{
Efficiency of Lactation
}

\author{
Pouya Zamani
}

Additional information is available at the end of the chapter

http://dx.doi.org/10.5772/50772

\section{Introduction}

Dairy cows are one of the most efficient animals. Regarding to energy and protein yield per unit of land used, milk production is one of the most efficient enterprises in animal productions (Table 1). Likewise, the efficiency of solar energy used for production of energy and protein as milk is more efficient than other livestock products (Table 2). Moreover, efficiency of nutrient utilization is a major factor affecting profitability in modern dairy farms, because feed costs represent approximately one-half of the total costs in most livestock operations and $80 \%$ of the variable cost of milk production. (Milk Marketing Board, 1990). Thus, improvement of feed efficiency has a noticeable importance to increase profitability of lactating dairy cows.

\begin{tabular}{lcc}
\hline Yield & Crude protein $(\mathrm{kg} / \mathrm{ha} / \mathrm{yr})$ & Gross energy $(\mathrm{MJ} / \mathrm{ha} / \mathrm{yr})$ \\
\hline Cow milk & 145 & 12000 \\
Beef & 31 & 2400 \\
Lamb & 22 & 2500 \\
Pork & 76 & 11400 \\
Broiler's meat & 145 & 4300 \\
\hline
\end{tabular}

Table 1. Energy and protein yielded by meat and milk productions per unit of land used (Spedding et al., 1981)

\begin{tabular}{lcc}
\hline Yield & Protein (gr) & Energy (MJ) \\
\hline Cow milk & 0.0044 & 0.00036 \\
Beef & 0.0009 & 0.00007 \\
Lamb & 0.0007 & 0.00008 \\
Pork & 0.0023 & 0.00035 \\
Egg & 0.0034 & 0.00018 \\
\hline
\end{tabular}

Table 2. Efficiency of solar energy used for production of energy and protein as different animal productions (Spedding et al., 1981)

* As received radiation of $33 \times 10^{6} \mathrm{MJ} / \mathrm{ha} / \mathrm{yr}$ 
Dairy cows excrete about 2-3 times more nitrogen $(\mathrm{N})$ in manure than in milk, which contributes to increased milk production costs and environmental $\mathrm{N}$ pollution (Broderick, 2005). Mass $\mathrm{N}$ balance studies showed that on typical dairy farms only 12 to $36 \%$ of the $\mathrm{N}$ input is retained in salable products, whereas up to about $70 \%$ is lost mainly through volatilization and leaching into the off-farm environment (Ipharraguerre and Clark, 2005). These evidences reveal that improving a cow's biological efficiency for converting feed to milk should be an important goal for the dairy industry and in animal breeding programs.

\section{Measures of efficiency}

There are several criteria to measure feed efficiency in lactating dairy cows. The most important measures of feed efficiency could be mentioned as follow.

\subsection{General efficiency}

This category of feed efficiency measures refers to the simple ratio criteria such as gross feed efficiency and feed conversion ratio.

Feed conversion ratio (FCR): The ratio of feed intake over milk yield is called feed conversion ratio (Equation 1). By this measure, a less feed conversion ratio means more efficiency.

$$
F C R=\frac{D M I}{M Y}
$$

Where, DMI and MY are dry matter intake and milk yield, respectively.

Gross feed efficiency (GFE): This measure can be described as the ratio of milk produced to feed consumed. Gross feed efficiency is inversed of feed conversion ratio. (Equation 2)

$$
G F E=\frac{M Y}{D M I}
$$

In calculation of FCR and GFE, milk compositions are ignored. To overcome this problem, fat corrected milk yield or solid corrected milk yields could be used for calculation of FCR and GFE.

Another problem arising from feed conversion ratio and gross feed efficiency is that the nutrient composition of feed intake affects the efficiency of animal. For example, a concentrated diet will improve the efficiency (decreased FCR and increased GFE). To overcome this problem, the efficiency could be determined for main dietary components, including energy and protein.

\subsection{Energetic efficiency}

Energetic efficiency is a common measure of biological efficiency, because energy is the most limiting nutrient for dairy cow, and the intake of which is most closely related to the 
level of milk production; furthermore, protein is a form of feed energy and accounted for in calculations of energetic efficiency as well (VandeHaar, 1998).

Several criteria for the measurement of energetic efficiency have been proposed. The most important measures of energetic efficiency are gross energy efficiency, net energy efficiency and residual feed intake.

Gross energy efficiency (GEE): Gross energy efficiency is the percentage of a given category of feed energy recovered in milk (Brody, 1945). GEE could be calculated by Equation 3.

$$
G E E=\frac{E C M}{E I}
$$

In this equation, ECM and EI are energy contents of milk and energy intake, respectively.

Gross energy efficiency does not consider the role of body reserves in energetic efficiency of lactating cows. For example, at the first stages of lactation, when the cow is in negative energy balance, a considerable amount of energy is taken from body tissues and the cow seems more efficient in at these stages of lactation. Vice versa, at the last stages of lactation, a considerable energy is stored in the body tissues and the cow sounds less gross energy efficiency. This problem could be eliminated by the next measure of efficiency, called net energy efficiency.

Net energy efficiency (NEE): Net energy efficiency is the ratio of energy contained in the milk over the available portion of energy intake used to produce it above maintenance requirements (Brody, 1945; Buttazzoni and Mao, 1989; Miraei-Ashtiani et al, 2005). NEE could be calculated using Equation 4.

$$
N E E=\frac{E C M}{M E I-N E_{m}-N E_{\text {preg }}-E R}
$$

Where, ECM is energy content of produced milk and MEI, NEm, NEpreg and ER are metabolizable energy intake, energy requirement for maintenance, energy requirement for pregnancy and net energy required for replenishment of reserves or net energy available if reserves are mobilized.

Feed conversion ratio, gross feed efficiency, and gross and net energy efficiencies are calculated as ratios. When feed efficiency is expressed as a ratio, there may be two disadvantages (Wang et al, 1992): the first is an increase in the error variance as a proportion of total variance in the statistical analysis (Lison, 1958) and the second is a strong positive phenotypic and genetic correlations between milk yield and feed efficiency which could be the result of an almost automatic correlation (Mason et al, 1957). To overcome the probable problems of ratio measures, an alternative linear calculating criterion could be more appropriate to measure energetic efficiency. The next measure, called residual energy intake, has a linear calculating method. 
Residual energy intake (REI): Residual energy intake or residual feed intake (RFI) can be defined as the difference between actual energy intake and the one predicted on the basis of requirements for maintenance, lactation, and body weight change of an animal (Equation 5). Residual energy intake seems to have been first proposed by Koch et al. (1963) and then studied by other researchers (e.g. Kennedy et al., 1993; Veerkamp et al., 1995; Zamani et al., 2008).

$$
R E I=A E I-P E I
$$

In this equation, AEI and PIE are actual and predicted energy intakes, respectively.

Energy intake could be predicted using energy requirement prediction models, such as NRC (National Research Council, 2001) and so on. But the most proper and traditional method is prediction of energy intake regarding to the population studied. In this method, energy intake is predicted using a regression model, fitting actual energy intake on some independent variables such as milk yield, milk compositions, body weight and body weight change, thus residual effect of the fitted model will be residual energy intake.

In this method, the average of REI in the population is zero, whereas the animals with negative REI are more efficient and the animals with positive REI are less efficient in use of energy intake (Figure 1). In another word, more efficient animals use more proportion of the energy intake for production, thus their actual energy intake is less than the prediction, so have negative REI.

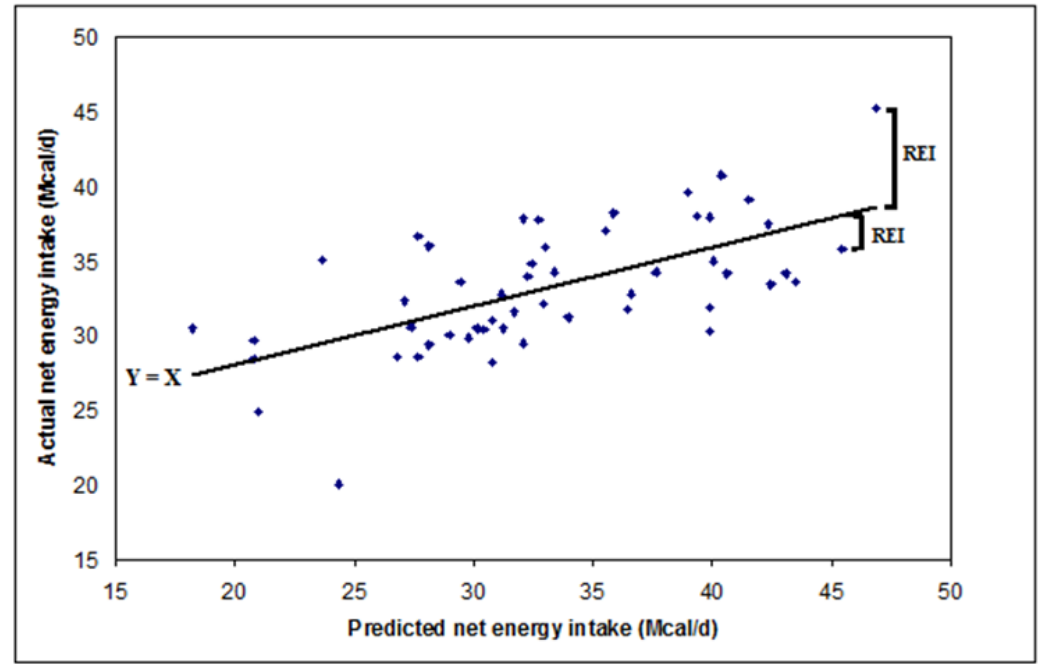

Figure 1. Residual energy intake (REI) as the difference between actual and predicted energy intakes. The animals over the regression line have positive REI (less efficient) and the animals under the line have negative REI (more efficient). 


\subsection{Protein efficiency}

As it was mentioned before, dairy cows excrete about 2 to 3 times more $\mathrm{N}$ in manure than in milk, which contributes to increased costs of milk production and environmental $\mathrm{N}$ pollution (Broderick, 2005). Thus, recently, attention has focused on the relationship between nitrogen utilization in lactating cows and environmental pollution (Castillo et al, 2000).

Different criteria could be used to measure protein efficiency of lactation. For example, gross efficiency of crude protein (Huhtanen et al, 2008; Zamani et al, 2011a and 2011c), crude protein balance (Zamani et al, 2011a and 2011b) and residual protein intake (Zamani et al, 2011a) have been studied in literature.

Gross efficiency of crude protein (GECP): Gross efficiency of crude protein is the proportion of feed CP recovered in milk (Equation 6).

$$
G E C P=\frac{C P M}{C P I}
$$

Where, CPM and CPI are CP produced in milk and CP intake, respectively.

Crude protein balance $(C P B)$ : Crude protein balance could be calculated as the difference between $\mathrm{CP}$ intake and protein excreted in milk (Equation 7), where the most efficient cattle present higher dietary protein recovery and consequently a lower CPB.

$$
C P B=C P I-C P M
$$

In this equation, $\mathrm{CPI}$ and $\mathrm{CPM}$ are $\mathrm{CP}$ intake and $\mathrm{CP}$ produced in milk, respectively.

Residual protein intake (RPI): Residual protein intake is similar to residual energy intake and is defined as the difference between actual and predicted CP intakes (Equation 8).

$$
R P I=A P I-P P I
$$

Where, API and PPE are actual and predicted protein intakes, respectively.

RPI is a measure of protein efficiency, because more efficient cows present lower protein intake for the same protein excretion in milk and body weight change and thus, have a lower RPI (Zamani et al, 2011a).

\subsection{Economic efficiency}

Economic efficiency is the most important goal for animal production enterprises. In dairy herds, several economic criteria such as economic selection index or economic merit (Veerkamp, 1998), the ratio of total costs to total incomes (Goddard, 1997) and proportion of total costs per unit of yield (Dickerson, 1970; Newman et al, 1985) are proposed in literature.

Generally, in dairy farms the profitability of a lactating cow is dependent on both outputs (incomes of milk, fat, protein, calving, etc.) and inputs (costs of feed, labour, facilities, etc). 
Feed is the major cost input for all livestock farmers, including dairy producers (Harris and Newman, 1994) and has the highest correlation to profit (Balaine et al, 1981). Therefore, increase of main incomes (milk, fat and protein) and reduce of main variable cost (feed) potentially can be of considerable importance in profitability of dairy cows. Income over feed cost (IOFC) is defined as the income from milk, fat and protein yields minus the feed cost (Equation 9) and has been studied as an economic index for lactating dairy cows in several studies, such as Adkinson et al (1993), Baars (1998), Kelm et al (2000), Miraei-Ashtiani et al (2005) and Zamani et al (2004 and 2005).

$$
I O F C=G I-F C
$$

Where, IOFC, GI and FC are income over feed cost, gross income and feed cost, respectively.

\section{Factors affecting efficiency of lactation}

Efficiency of lactation is affected by different factors. Some of the practical factors affecting efficiency of energy and protein use are the level of milk production, type of diet, body size, changes in body tissue mass during lactation, environmental conditions, exercise, age at first calving, productive lifespan, genetics, metabolic modifiers, and growth rate as a heifer (VandeHaar, 1998). Moreover, other factors such as season, breed, parity number, days in milk and milking frequency are also proposed to have significant effects on the efficiency of lactation (Zamani, 2005).

Among different factors affecting efficiency of lactation, level of production is one of the most important factors, whereas higher milk production is associated with more efficient partitioning of feed nutrients (VandeHaar, 1998). In many studies, milk yield had a positive phenotypic and genetic correlation to efficiency (e.g. Korver, 1988; Buttazzoni and Mao, 1989; Britt et al, 2003; Miraei-Ashtiani et al, 2005; Zamani, 2005). However, it has been shown that the efficiency of protein use has a negative correlation to milk yield (Zamani et al, 2011a). The effect of nutrition and genetic on efficiency will be discussed in this section.

\subsection{Nutritional factors}

Nutritional factors have noticeable effects on the efficiency. Too many nutritional factors could be mentioned to have an effect on the efficiency. But, some of the most important factors will be discussed here.

Source of energy is one of the most important factors, affecting energetic efficiency of feed (Smith, 1988). It is shown that the net efficiency of converting fiber to milk is less than that for starch and protein, and the net efficiency of converting dietary fat to milk is greater. This increased efficiency of fat is mostly due to a decrease in heat increment and thus an increase in partial efficiency of converting ME to NEL (VandeHaar, 1998). However, proper ratios of structural and non-structural carbohydrates, fat and protein must be included in diet to ensure proper function of ruminal microorganisms and whole digestive tract (Fox et al, 1992). 
Dietary level of energy is also affecting the efficiency. Zamani et al (2011b) reported that a slight increase in dietary energy probably increases protein efficiency for lactation. This finding could be attributed to an increase of fermentable metabolizable energy (FME) in most of high NEL diets, because FME provides the energy needed to supply rumen microbes for capture of $\mathrm{N}$. Moreover, the fate of absorbed peptides and amino acids once inside the microbial cell will depend on availability of energy. If energy is available, amino acids will be trans-aminated or used directly for microbial protein synthesis, otherwise, if energy is limiting, amino acids will be de-aminated and their carbon skeleton will be fermented (Bach et al., 2005).

In addition to dietary energy, dietary $\mathrm{CP}$ could also affect the efficiency. Producers often feed high CP diets to ensure a sufficient supply of the metabolizable protein required for maximal milk and protein production of dairy cows. Excess levels of dietary protein or high degradability of dietary crude protein increases ammonia production in the rumen and as a result, ammonia concentration in the plasma increases. More rate of ammonia conversion to urea in liver needs more energy consumption (Martin and Blaxter, 1965) and thus, reduced energetic efficiency. Negative correlation of dietary level of $\mathrm{CP}$ with gross energy efficiency has been reported by Zamani (2005).

Feeding excess protein has a high energetic cost. The energetic cost of feeding $1 \mathrm{~kg}$ of extra $\mathrm{CP}$ is equivalent to $0.72 \mathrm{Mcal}$ of NEL (Oldham, 1984). If a cow producing $45 \mathrm{~kg}$ of milk/day and eating $25 \mathrm{~kg}$ of $\mathrm{DM} /$ day required $17 \% \mathrm{CP}$ in its diet, then feeding an extra $2 \% \mathrm{CP}$ (a diet with $19 \% \mathrm{CP}$ ) would cost $0.36 \mathrm{Mcal} \mathrm{NE} / \mathrm{day}$, decrease milk yield by $0.5 \mathrm{~kg} / \mathrm{day}$, and gross efficiency by 0.3 percentage points (VandeHaar, 1998).

Some reports indicate that feeding diets with excessively high $\mathrm{CP}$ concentration and especially excess ruminally degradable $\mathrm{CP}$, also decreases protein efficiency in lactating dairy cows (Olmos Colmenero and Broderick, 2006; Wang et al., 2007; Huhtanen et al., 2008; Zamani et al, 2011b and 2011c). Moreover, overfeeding CP reduces profit margins, because of the relatively high cost of protein supplements and poor efficiency of dairy cows fed high protein diets to utilize N (Broderick, 2003).

This has been reported that an increase in the ruminally undegradable protein (RUP)/ ruminally degradable protein (RDP) ratio may improve protein efficiency (Zamani et al, 2011b and 2011c), because at a high RDP level, more N would be absorbed as ammonia or more amino acids deaminated, which might increase $\mathrm{N}$ excretion in urine (Castillo et al, 2001). The positive effect of RUP on protein efficiency is also reported by Flis and Wattiaux (2005) and Kalscheur et al (2006). Moreover, Castillo et al (2001) and Reynal and Broderick (2005) found that an increase in dietary CP degradability results in more urinary $\mathrm{N}$ excretion. However, post-ruminal digestibility of RUP and amino acids balance could be considered as an important factor for increasing metabolizable protein flow to the intestine (Noftsger and St-Pierre, 2003) and thus for optimizing dietary RUP to improve protein efficiency.

There are some reports about the effects of feed additives on the efficiency. For example, addition of buffers as sodium bicarbonate $\left(\mathrm{NaHCO}_{3}\right)$ and magnesium oxide $(\mathrm{MgO})$ reduced gross energy efficiency for milk production (Arambel et al, 1988). 
These findings reveal that many nutritional factors may affect the efficiency of lactation. Generally, it is necessary to optimize different dietary components to maximize efficiency of lactation.

\subsection{Genetic factors}

Many evidences show genetic variation of the lactation efficiency. In several studies, the cows selected for high yield traits were more efficient in use of feed for milk production (Dunklee et al, 1994; Veerkamp et al, 1993, 1994, 1995).

There are many reports on estimates heritability $\left(\mathrm{h}^{2}\right)$ for different measures of feed efficiency. Heritability estimates for gross energy efficiency had a wide range of 0.09 to 0.86 (e.g. Van Arendonk et al, 1991; Li et al, 1998; Zamani, 2005).

Buttazzoni and Mao (1989) estimated a heritability of $0.32-0.49$ for net energy efficiency (NEE) of lactation. The estimate of heritability for NEE in another study was 0.34 (Miraei Ashtiani et al, 2005). In different studies NEE had moderate positive genetic correlations to milk yield. Genetic correlation of NEE to milk yield has reported from 0.51 by Miraei Ashtiani et al (2005) to 0.56 by Buttazzoni and Mao (1989).

Several studies have shown the genetic variation of residual energy intake (REI) in dairy cattle. Van Arendonk et al (1991) and Kennedy et al (1993) have reported heritability estimates of 0.19 and 0.14 , respectively for REI. Veerkamp et al (1995) reported a heritability of 0.30 to 0.38 for REI, depending on the way of calculating the energy requirements from phenotypic regressions. In another study, the estimated heritability and repeatability for REI were 0.15 and 0.53 from univariate, and 0.21 and 0.60 from multivariate models, respectively (Zamani et al, 2008). On the other hand, Ngwerume and Mao (1992) and Svendsen et al (1993) found no evidence for any additive genetic variation in REI, where they have reported heritability estimates of 0.016 and $0.00-0.11$ for REI, respectively. Unlike to other measures of efficiency, REI is, to some extent, independent of yield traits. In different studies REI had low and negative genetic correlations with milk yield (Madgwick et al, 1991; Van Arendonk et al, 1991; Kennedy et al, 1993; Veerkamp et al, 1995; Zamani et al, 2008).

Genetic variation of protein efficiency has been rarely studied in dairy cattle. Li et al. (1998) reported a value of 0.13 as estimate of heritability for crude protein efficiency of lactation. In another study, heritability estimates for crude protein efficiency in 90 and 305 days of lactation were 0.10 and 0.31, respectively (Ageeb, 1999). In a recent study Zamani et al (2011a) reported heritability estimates of $0.07,0.40$ and 0.03 for gross efficiency of crude protein, crude protein balance and residual protein intake, respectively. In their study, noticeable genetic correlations were observed between different measures of protein efficiency and some of yield traits. In this study this has been proposed that the protein efficiency could be improved by direct selection against crude protein balance, while other measures of protein efficiency, including gross efficiency of crude protein and residual protein intake did not seem to be suitable for direct selection. They proposed the selection 
for milk fat and protein percentages as an effective way for indirect improvement of protein efficiency (Zamani et al, 2011a).

\section{Implications}

Efficiency of nutrient utilization is a major factor affecting profitability in modern dairy farms. Several criteria are used to measure efficiency of lactation. Different measures of feed efficiency could be categorized as general, energetic, protein and economic criteria. Feed efficiency is controlled by different environmental and genetic factors. Feed efficiency could be improved by optimizing environmental effects, including nutritional factors, direct selection for feed efficiency or indirect selection for feed efficiency by the selection on yield traits.

\section{Author details}

Pouya Zamani

Department of Animal Science, Bu-Ali Sina University, Hamedan, Iran

\section{References}

Adkinson, R.W., W.S. Farmer and B.F. Jenny, 1993. Feeding practices and income over feed cost on pasture-oriented dairy farms in Louisiana. J. Dairy Sci., 76:3547-3554.

Ageeb, A.G.A., 1999. Genetic relationships among feed intake measures, feed conversion efficiency, and milk production traits in Holsteins using field recorded data. $\mathrm{PhD}$ Thesis. Macdonald College of McGill University. Montreal. Canada.

Arambel, M.J., R.D. Weidmeier, D.H. Clark, R.C. Lamb, R.L. Bowman and J.L. Walters, 1988. Effect of sodium bicarbonate and magnesium oxide in an alfalfa-based total mixed ration fed to early lactating dairy cattle. J. Dairy Sci., 71: 159-163.

Baars, R.M.T., 1998. Nutrition management, nitrogen efficiency and income over feed cost on dairy farms in Costa Rica. J. Dairy Sci., 81: 801-806.

Bach, A., S. Calsamiglia and M.D. Stern, 2005. Nitrogen metabolism in the rumen. J. Dairy Sci. 88 (E. Supple.): E9-E21.

Balaine, D.S., R.E. Pearson and R.H. Miller, 1981. Profit functions in dairy cattle and effect of measures of efficiency and prices. J. Dairy Sci., 64: 87-95.

Britt, J.S., R.C. Thomas, N.C. Speer and M.B. Hall, 2003. Efficiency of converting nutrient dry matter to milk in Holstein herds. J. Dairy Sci., 86: 3796-3801.

Broderick, G.A., 2003. Effects of varying dietary protein and energy levels on the production of lactating dairy cows. J. Dairy Sci., 86: 1370-1381.

Broderick, G.A., 2005. Feeding dairy cows to minimize nitrogen excretion. Proc. Tri-State Dairy Nutrition Conference 2005. 137-152.

Brody, S. 1945. Bioenergetics and growth. Reinhold Publ. Co. New York. NY.

Buttazzoni, L. and I.L. Mao, 1989. Genetic parameters of estimated net energy efficiencies for milk production, maintenance and body weight change in dairy cows. J. Dairy Sci. 72: 671-677. 
Castillo, A.R., E. Kebreab, D.E. Beever and J. France, 2000. A review of efficiency of nitrogen utilisation in lactating dairy cows and its relationship with environmental pollution. J. Anim. Feed Sci., 9: 1-32.

Castillo, A.R., E. Kebreab, D.E. Beever, J.H. Barbi, J.D. Sutton, H.C. Kirby and J. France, 2001. The effect of protein supplementation on nitrogen utilization in lactating dairy cows fed grass silage diets. J. Anim. Sci., 79: 247-253.

Dickerson, G.E., 1970. Efficiency of animal production-modeling the biological components. J. Anim. Sci., 30: 849-859.

Dunklee, J.S., A.E. Freeman and D.H. Kelley, 1994. Comparison of Holsteins selected for high and average milk production. 1. Net income and production response to selection for milk. J. Dairy Sci., 77: 1890-1896.

Flis, S.A. and M.A. Wattiaux, 2005. Effects of parity and supply of rumen-degraded and undegraded protein on production and Nitrogen balance in Holsteins. J. Dairy Sci., 88: 2096-2106.

Fox, D.G., C.J. Sniffen, J.D. O'Connor, P.J. Van Soest and J.B. Russell, 1992. A net carbohydrate and protein system for evaluating cattle diets. III. Cattle requirements and diet adequacy. J. Anim. Sci., 70: 3578-3596.

Goddard, M.E., 1997. Consensus and debate in the definition of breeding objectives. J. Dairy Sci., 80 (Suppl. 1): 144. (Abstr.)

Harris, D.L. and S. Newman, 1994. Breeding for profit: Synergism between genetic improvement and livestock production (a review). J. Anim. Sci., 72: 2178-2200.

Huhtanen, P., J.I. Nousiainen, M. Rinne, K. Kytölä and H. Khalili, 2008. Utilization and partition of dietary nitrogen in dairy cows fed grass silage-based diets. J. Dairy Sci., 91: 3589-3599.

Ipharraguerre, R. and J.H. Clark, 2005. Varying protein and starch in the diet of dairy cows. II. Effects on performance and Nitrogen utilization for milk production. J. Dairy Sci., 88, 2256-2570.

Kalscheur, K.F., R.L. Baldwin, B.P. Glenn and R.A. Kohn, 2006. Milk production of dairy cows fed differing concentrations of rumen-degraded protein. J. Dairy Sci., 89: 249-259.

Kelm, S.C., A.E. Freeman and NC-2 Technical Committee, 2000. Direct and correlated responses to selection for milk yield: results and conclusions of regional project NV-2, "Improvement of dairy cattle trough breeding, with emphasis on selection". J. Dairy Sci., 83: 2721-2732.

Kennedy, B.W., J.H.J. van der Werf and T.H.E. Meuwissen, 1993. Genetic and statistical properties of residual feed intake. J. Anim. Sci., 71: 3239-3250.

Koch, R.M., L.A. Swiger, D. Chambers and K.E. Gregory, 1963. Efficiency of food use in beef cattle. J. Anim. Sci., 22: 486-494.

Korver, S., 1988. Genetic aspects of feed intake and feed efficiency in dairy cattle. A review. Livest. Prod. Sci., 20: 1-13.

Li, J., D. Chen and S. Xu, 1998. The analysis on genetic factors of feed energy and protein efficiency of Chinese Simmental. Proc. 6th World Congr. Gen. Appl. Livest. Prod. NSW, Australia, 25: 133-136. 
Lison, L., 1958. Statistique appliquée à la biologie expérimentale. Gauthier-Villars ÉditeurImprimeur-Libraire, Paris, France.

Madgwick, P.P., K.A. Beard and M.E. Goddard, 1991. Possibilities for incorporating selection for feed conversion efficiency into the national dairy herd improvement program. Proc. 9th Mtg. Assoc. Adv. Anim. Br. Gen., Australia. 1991; 45-48.

Martin, A.K. and K.L. Blaxter, 1965. The energy cost of urea synthesis in sheep. In: K.L. Blaxter, (ed.) Energy Metabolism of Farm Animals. Academic Press, London, UK. Pages 83-91.

Mason, I.L., A. Robertson and B. Gjelstad, 1957. The genetic connection between body size, milk production and efficiency in dairy cattle. J. Dairy Res., 24: 135-143.

Milk Marketing Board, 1990. Report of the farm services division, 1988/89. No. 39. MMB, Thames Ditton, Surrey, UK.

Miraei Ashtiani, S.R., P. Zamani, A. Nikkhah, M. Moradi-Shahrbabak, A. Naserian and F. Akbari, 2005. Study the importance of net energy efficiency in breeding programs of Holstein dairy cattle. J. Sci. Tech. Agr. Nat. Resour., 9: 201-209.

National Research Council, 2001. Nutrient requirements of dairy cattle. National Academy Press, Washington, DC. USA.

Ngwerume, F. and I.L. Mao, 1992. Estimation of residual energy intake for lactating cows using an animal model. J. Dairy Sci., 75: 2283-2287.

Newman, S., D.L. Harris and D.P. Doolittle, 1985. Economic efficiency of lean tissue production through crossbreeding: Systems modeling with mice. I. Definition of the bioeconomic objective. J. Anim. Sci., 60: 385-394.

Noftsger, S. and N.R. St-Pierre, 2003. Supplementation of Methionine and selection of highly digestible rumen undegradable protein to improve Nitrogen efficiency for milk Production. J. Dairy Sci., 86: 958-969.

Olmos Colmenero, J.J. and G.A. Broderick, 2006. Effect of dietary crude protein concentration on milk production and Nitrogen utilization in lactating dairy cows. J. Dairy Sci., 89: 1704-1712.

Oldham, J.D., 1984. Protein-energy interrelationships in the dairy cows. J. Dairy Sci., 67: 1090-1114.

Reynal, S.M. and G.A. Broderick, 2005. Effect of dietary level of rumen-degraded protein on production and Nitrogen metabolism in lactating dairy cows. J. Dairy Sci., 88: 40454064 .

Smith, N.E. 1988. Alteration of efficiency of milk production in dairy cows by manipulation of the diet. In: P.C. Garnsworthy, (ed.) Nutrition and Lactation in the Dairy Cow. Butterworth, London, UK. Pages 216-231.

Spedding, C.R.W., J.M. Walsingham and A.M. Hoxey, 1981. Biological efficiency in agriculture. Academic Press. USA.

Svendsen, M., P. Skipenes and I.L. Mao, 1993. Genetic parameters in the feed conversion complex of primiparous cows in the first two trimesters. J. Anim. Sci., 71: 1721-1729.

Van Arendonk, J.A.M., G.L. Nieuwhof, H. Vos and S. Korver, S., 1991. Genetic aspects of feed intake and efficiency in lactating dairy heifers. Livest. Prod. Sci., 29: 263-275. 
VandeHaar, M.J., 1998. Efficiency of nutrient use and relationship to profitability on dairy farms. J. Dairy Sci. 81: 272-282.

Veerkamp, R.F., 1998. Selection for economic efficiency of dairy cattle using information on live weight and feed intake: a review. J. Dairy Sci., 81: 1109-1119.

Veerkamp, R.F., G.C. Emmans, A.R. Cromie and G. Simm, 1995. Variance components for residual feed intake in dairy cows. Livest. Prod. Sci., 41: 111-120.

Veerkamp, R.F., G.C. Emmans, J.D. Oldham and G. Simm, 1993. Energy and protein utilization of cows of high and low genetic merit for milk solids production on a high and low input diet. Proc. Zodiac Symp. Biological basis of sustainable animal production. Wageningen, EAAP, No. 67.

Veerkamp, R.F., G. Simm and J.D. Oldham, 1994. Effects of interaction between genotype and feeding system on milk production, feed intake, efficiency and body tissue mobilization in dairy cows. Livest. Prod. Sci., 39: 229-241.

Wang, C., J.X. Liu, Z.P. Yuan, Y.M. Wu, S.W. Zhai and H.W. Ye, 2007. Effect of level of metabolizable protein on milk production and Nitrogen utilization in lactating dairy cows. J. Dairy Sci., 90: 2960-2965.

Wang, S., G.L. Roy, A.J. Lee, A.J. McAllister, T.R. Batra, C.Y. Lin, J.A. Vesely, J.M. Wauthy and K.A. Winter, 1992. Evaluation of various measures of and factors influencing feed efficiency of dairy cattle. J. Dairy Sci., 75: 1273-1280.

Zamani, P., 2005. Different measures of energetic efficiency of lactation and estimation of their genetic parameters in Holstein dairy cattle. PhD thesis, Department of Animal Science, University of Tehran.

Zamani, P., S.R. Miraei-Ashtiani and H. Mohammadi, 2008. Genetic parameters of residual energy intake and its correlations with other traits in Holstein dairy cattle. Turk. J. Vet. Anim. Sci., 32: 255-261.

Zamani, P., S.R. Miraei-Ashtiani, D. Alipour, H. Aliarabi and A.A. Saki. 2011a. Genetic parameters of protein efficiency and its relationships with yield traits in lactating dairy cows. Livest. Sci., 138: 272-277.

Zamani, P., S.R. Miraei-Ashtiani, D. Alipour, H. Aliarabi, A.A. Saki, M. Maleki and A Abdolmohammadi, 2011b. Statistical analysis of some factors affecting crude protein balance in lactating dairy cows. J. Agr. Sci. Tech., (In Press).

Zamani, P., S.R. Miraei-Ashtiani, D. Alipour, M.M. Tabatabaei, H. Aliarabi, A.A. Saki, A. Ahmadi and K. Zaboli, 2011c. Statistical evaluation of some environmental factors affecting gross efficiency of crude protein in high producing dairy cow. Turk. J. Vet. Anim. Sci., 35: 123-130.

Zamani, P., S.R. Miraei-Ashtiani, A.A. Naserian, A. Nikkhan, and M. Moradi Shahrbabak. 2004. Genetic variation in residual energy intake and its association with body weight, milk yield, fat corrected milk yield and economic merit in dairy cattle. J. Dairy Sci., 87 (Supple 1): M9, Page: 3. (Abstract).

Zamani. P., S.R. Miraei-Ashtiani, A.A. Naserian, A. Nikkhan, and M. Moradi Shahrbabak. 2005. Genetic variation of income over feed costs as an individual trait in Holstein cows. Proceedings of the British Society of Animal Science. Page: 130. 